\title{
Ascorbic acid levels in maternal milk: differences with respect to ascorbic acid status during the third trimester of pregnancy
}

\author{
Rosa M. Ortega ${ }^{1}$, M. Elena Quintas ${ }^{1}$, Pedro Andrés ${ }^{2}$, Rosa M. Martínez $^{3}$ and Ana M. López-Sobaler ${ }^{1}$ \\ ${ }^{1}$ Departamento de Nutrición, Facultad de Farmacia, Universidad Complutense, Madrid, Spain \\ ${ }^{2}$ Laboratorio de Técnicas Instrumentales, Facultad de Farmacia, Universidad Complutense, Madrid, Spain \\ ${ }^{3}$ Servicio de Análisis Clínicos, Servicio de Obstetricia y Ginecología, Hospital INSALUD, Cuenca, Spain
}

(Received 25 September 1997 - Revised 3 November 1997 - Accepted 25 November 1997)

\begin{abstract}
The aim of the present investigation was to study the relationship between ascorbic acid status during the third trimester of pregnancy and levels of this vitamin in transition milk (days 13-14 of lactation) and mature milk (day 40 of lactation). To this end, the pregnancies and lactation periods of fifty-seven healthy women between 18 and 35 years of age (27 (SD 3.7) years) were monitored. Vitamin intake during the third trimester was determined by recording the consumption of foods over $5 \mathrm{~d}$, and by registering the quantities provided by dietary supplements. Ascorbic acid levels in maternal serum during this stage of pregnancy, and in transition and mature milk samples, were determined by spectrophotometry. Those subjects with ascorbic acid intakes below that recommended $(80 \mathrm{mg} / \mathrm{d}$ ) (group L) showed lower consumption of fruit and vegetables than did those with greater intakes (group $\mathrm{H}$ ). The consumption of ascorbic acid supplements was very low, and was only seen in three group $\mathrm{H}$ subjects. The difference in ascorbic acid intake was reflected at serum level. Group L subjects showed significantly lower serum values than did group $H$ subjects ( 30.1 (SD 36.3 ) $\mu$ mol/1 compared with 101.1 (SD 168.1) $\mu \mathrm{mol} / \mathrm{l}$ ). Vitamin intake also influenced the composition of transition milk. Group L subjects showed significantly lower levels of ascorbic acid in milk than did group $\mathrm{H}$ subjects (255.5 (SD 220.3) $\mu \mathrm{mol} / \mathrm{l}$ compared with 437.8 (SD 288.4) $\mu \mathrm{mol} / \mathrm{l}$ ). The results of the present study reveal the need to increase the consumption of fruits and vegetables during pregnancy and to monitor maternal ascorbic acid intake and vitamin $\mathrm{C}$ status.
\end{abstract}

\section{Ascorbic acid: Pregnancy: Lactation}

Adequate nutrition during pregnancy and lactation is extremely important to both maternal and fetal health (Zeman \& Ney, 1988). As nutritional requirements are high, the effects of malnutrition can be severe and long lasting in pregnant and lactating mothers. Nutritional status during these periods may, therefore, be a contributing factor in maternal and infant morbidity and mortality (González-Cossio \& Delgado, 1991).

Specific nutrient deficiencies may affect a woman's functional capacity and increase her susceptibility to unfavourable perinatal processes (Antal et al. 1997). With regard to ascorbic acid, some studies on pregnant women have revealed that ascorbic acid deficiency is associated with increased risk of infections, premature rupture of the membranes (Casanueva et al. 1993; Pfeffer et al. 1996), prematurity (Tlaskal \& Novakova, 1990; Casanueva et al. 1993) and eclampsia (King \& Weininger, 1991; Jendryczko \& Tomala, 1995).

The aim of the present investigation was, therefore, to study the relationship between ascorbic acid status during the third trimester of pregnancy and levels of this vitamin in maternal milk.

\section{Materials and methods}

The pregnancies and lactation periods of fifty-seven women were followed. The characteristics of the subjects and criteria of inclusion or exclusion have been reported in previous papers (Ortega et al. 1997a,b).

\footnotetext{
Abbreviations: MTT, 3-(4,5-dimethylthiazoyl-2)-2,5 diphenyltetrazolium bromide.

*Corresponding author: Professor Rosa Ortega, fax +341394 1732, email rortega@eucmax.sim.ucm.es
} 
The study protocol was approved by the Comité de Investigación de la Facultad de Farmacia, Universidad Complutense de Madrid and by the Comité Etico del Hospital del INSALUD de Cuenca.

During the third trimester (between weeks 32 and 36), dietary, anthropometric and biochemical studies were made. After subjects gave birth the study continued. The composition of subjects' (now lactating mothers) milk was analysed at days 13-14 (transitional milk) and 40 (mature milk) (Patton et al. 1990).

\section{Diet survey}

Food intake was recorded by keeping a 'food record" questionnaire for $5 \mathrm{~d}$, including a Sunday. Kitchen scales were provided to all the subjects in order to facilitate the weighing of food. After the questionnaire was completed, the booklets were returned in person. A qualified nutritionist inspected the records to ensure that they were complete and that sufficient detail had been recorded. In the same interview a food-frequency questionnaire was completed in order to contrast subjects' answers with the results of their $5 \mathrm{~d}$ dietary record, and an explanation was requested if answers were inconsistent. Details of the diet survey method used have been published previously (Ortega et al. 1997a,b).

The ascorbic acid content of foods consumed was calculated using tables of food composition published by the Instituto de Nutrición (1994). The recommended intake of ascorbic acid accepted in this study $(80 \mathrm{mg} / \mathrm{d})$ was that for women in the second half of pregnancy as established in the tables of recommended energy and nutrient intakes for the Spanish population (Departamento de Nutrición, 1994).

The intake of supplements was recorded by asking subjects what, and how much, they had taken during pregnancy. This was then added to the quantity of ascorbic acid provided by the diet. The adequacy of the diet with respect to ascorbic acid was determined by comparing this value with that recommended.

Estimates of $24 \mathrm{~h}$ energy expenditure were made using equations proposed by WHO (1985) multiplied by an activity ratio in accordance with the criteria of several expert groups (WHO, 1985; Departamento de Nutrición, 1994).

The percentage of discrepancy in reporting was established in accordance with Johnson et al. (1994) using the following formula: (energy expenditure - energy intake) $\times 100 /$ energy expenditure. When this method is used, a negative value indicates a reported energy intake greater than the predicted total energy expenditure (over-reporting) and a positive value denotes a reported energy intake less than the predicted total energy expenditure (under-reporting) (Johnson et al. 1994; Ortega et al. 1996b).

\section{Biochemical study}

Blood samples were taken first thing in the morning from night-fasted subjects. Since ascorbic acid is unstable in storage (Anderson \& Pittard, 1985), the serum component was separated and ascorbic acid levels determined color- imetrically (Henniger, 1981) (Boehringer Mannheim Biochemicals, Mannheim, Germany) immediately after extraction. Two samples were prepared from the collected serum. In one sample the oxidation of all reducing compounds, including L-ascorbic acid, was performed in the presence of methylsulphate-5-methylbenzene, reducing the tetrazolium salt 3-(4,5-dimethylthiazoyl-2)-2,5 diphenyltetrazolium bromide (MTT) to give dehydroascorbic acid plus MTT-formazan. In the presence of $\mathrm{O}_{2}$, ascorbic acid oxidase ( $E C$ 1.10.3.3) was added to the blank sample, to form dehydroascorbic acid exclusively. The colour due to ascorbic acid was therefore eliminated. The difference between absorbance of the test sample and that of the blank was taken to be the quantity of ascorbic acid in the sample. The quantity of MTT-formazan was used as the measurement variable, and was determined by the absorption recorded at $578 \mathrm{~nm}(\mathrm{CV} 4.8 \%)$.

Milk samples were taken at between 10.00 and 11.00 hours by manual expression of a $5 \mathrm{ml}$ sample from each breast at the beginning and end of a feed. The protocol for both collection and subsequent handling of milk has been described previously (Ortega et al. 1997a,b). After acidification of milk samples with citric acid to a $\mathrm{pH}$ of $3 \cdot 5-4.0$, followed by filtering (Beutler \& Beinstingl, 1980) (CV $4.9 \%$ ), milk ascorbic acid levels were determined by the method described earlier.

In order to establish normality limits for ascorbic acid in serum, the criteria of the following authors were taken into account: Kübler (1988) and Keller \& Salkeld (1988), who consider values between 11.4 and $142 \mu \mathrm{mol} / 1$ to be acceptable; Bates et al. (1983), who consider $17 \mu \mathrm{mol} / \mathrm{l}$ as the lower normal limit; and Dostálová (1984), who regards $<22.7 \mu \mathrm{mol} / \mathrm{l}$ as an indicator of high risk of deficiency, $22.7-34.1 \mu \mathrm{mol} / \mathrm{l}$ as a moderate risk, $>34.1 \mu \mathrm{mol} / 1$ as a low risk, and $>45.4 \mu \mathrm{mol} / \mathrm{l}$ as a very low risk (optimal situation). With respect to ascorbic acid levels in maternal milk, Byerley \& Kirksey (1985) have established $250 \mu \mathrm{mol} / 1$ as the lower normal limit.

\section{Anthropometric study}

Data were collected in the morning. Weight and height were determined for subjects without shoes and wearing only underwear, using a digital electronic weighing scale (Seca alpha, Igmy, France; range $0 \cdot 1-150 \mathrm{~kg}$ ) and a digital stadiometer (Harpenden Pfifter 450; Badem, Padum Aveny, Carlstadt, NJ, USA; range $0.70-2.05 \mathrm{~m}$ ) respectively. BMI $\left(\mathrm{kg} / \mathrm{m}^{2}\right)$ values were calculated from these data. All data were collected by trained personnel following norms set out by WHO (1976).

In order to see how anthropometric values changed during pregnancy, the values of these variables at the beginning of pregnancy were taken from subjects' clinical records. Weight and length of the newborn were measured immediately after birth.

\section{Other data}

Gestational age at delivery was calculated from the agreed delivery date recorded by the attending obstetrician, using 
last menstrual period and early ultrasound examination data. Data such as age, number of children previously borne and use of tobacco were recorded in a questionnaire during the first interview. Apgar scores (a neonatal condition score) at 1 and 5 min were measured.

\section{Statistical analysis}

Mean values and standard deviations are shown. Where the distribution of results was homogenous, the degree of significance of differences between means was calculated using Student's $t$ test. Where the distribution of results was not homogeneous, the Mann-Whitney test was applied. Differences were considered significant if $P<0.05$ (Wonnacott \& Wonnacott, 1977).

\section{Results}

For the presentation of data, subjects were grouped with respect to whether their ascorbic acid intakes were below (group L), or above (group $\mathrm{H}$ ) that recommended ( $80 \mathrm{mg} / \mathrm{d}$ ) (Tables $1-3)$. Table 1 shows both the mothers' and newborns' personal and anthropometric data, and reveals that there were no differences between the groups for any of these variables.

The discrepancy between energy intake and energy expenditure was positive, but no significant differences were seen between group L and group H subjects (15.6 (SD 20.8) \% compared with 9.4 (SD 19.1) \%).

Group L subjects showed significantly lower intakes of fruit (148.8 (SD 78.9) g/d) and vegetables (145.5 (SD 44.9) $\mathrm{g} / \mathrm{d}$ ) than did group $\mathrm{H}$ subjects $(398.1$ (SD 221.9) $\mathrm{g} / \mathrm{d}$ ) and 275.1 (SD 104.9) $\mathrm{g} / \mathrm{d}$ respectively). These differences are probably the reason for the greater intake of ascorbic acid seen in group $\mathrm{H}$ subjects (Table 2).
During the third trimester, only three group $H$ subjects took a supplement containing ascorbic acid, at quantities of $60-300 \mathrm{mg} / \mathrm{d}$. The dietary results were, therefore, hardly modified when supplements were taken into account (Table 2).

Serum and transition milk ascorbic acid levels were significantly higher in group $H$ subjects, whilst the proportion of subjects with serum levels below the normal limit was greater amongst group L subjects (Table 3 ).

\section{Discussion}

The duration of pregnancy and the anthropometric data of the mothers and their newborns (Table 1) were similar to those reported in other studies (Ortega et al. 1994, 1996a; Açkurt et al. 1995; Ash, 1995).

Since the percentage discrepancy between energy intake and energy expenditure (Johnson et al. 1994; Ortega et al. $1996 b$ ) was positive, subjects were probably guilty of under-reporting. Nevertheless, the WHO (1985) data are based on weight gains of $12.5 \mathrm{~kg}$ during pregnancy, whereas the pregnant women of the present study showed lower weight gains in the first two trimesters (Table 1). They also declared that they had considerably diminished their physical activity during pregnancy. It is possible, therefore, that the energy output of these subjects was lower than that established by WHO (1985). However, even if underestimation did take place, it can be seen that there were no differences in this respect between subjects in groups $\mathrm{L}$ and $\mathrm{H}$.

The intake of ascorbic acid observed during the third trimester was similar to that reported by other authors (Picone et al. 1982 (105 mg/d); Hunt et al. 1987 (83 mg/d); Borrud et al. 1993 (102 mg/d); Ortega et al. 1994 (174 (SD 81) mg/d); Job et al. 1995 (145 (SD 26) mg/d); Antal et al. 1997 (109.4 mg/d).

Table 1. Personal and anthropometric data for subjects and their newborns*

(Mean values and standard deviations)

\begin{tabular}{|c|c|c|c|c|c|}
\hline & \multicolumn{2}{|c|}{ Ascorbic acid intake $<\mathrm{RI}$} & \multicolumn{3}{|c|}{ Ascorbic acid intake $\geq$ RI } \\
\hline & Mean & SD & Mean & SD & \\
\hline$n$ & \multicolumn{2}{|c|}{12} & \multicolumn{2}{|c|}{45} & \\
\hline Age (years) & $27 \cdot 3$ & $4 \cdot 1$ & 27.5 & 3.8 & $\mathrm{H}$ \\
\hline \multicolumn{6}{|l|}{ Initial anthropometric data } \\
\hline Weight (kg) & $56 \cdot 4$ & 6.8 & 57.4 & $8 \cdot 6$ & $\mathrm{H}$ \\
\hline Height $(\mathrm{m})$ & 1.590 & 0.049 & 1.604 & 0.058 & $\mathrm{H}$ \\
\hline BMI $\left(\mathrm{kg} / \mathrm{m}^{2}\right)$ & $22 \cdot 1$ & 2.5 & 21.9 & $2 \cdot 2$ & $\mathrm{H}$ \\
\hline \multicolumn{6}{|l|}{ Anthropometric data in $3 \mathrm{rd}$ trimester } \\
\hline Weight (kg) & 64.4 & $6 \cdot 3$ & $66 \cdot 3$ & 8.5 & $\mathrm{H}$ \\
\hline Height $(\mathrm{m})$ & 1.590 & 0.048 & 1.604 & 0.057 & $\mathrm{H}$ \\
\hline BMI $\left(\mathrm{kg} / \mathrm{m}^{2}\right)$ & 25.0 & $2 \cdot 1$ & $25 \cdot 3$ & 2.4 & $\mathrm{H}$ \\
\hline Weight gain in first two trimesters $(\mathrm{kg})$ & $8 \cdot 0$ & $3 \cdot 3$ & 8.7 & 2.6 & $\mathrm{H}$ \\
\hline No. of children previously borne & 0.73 & 0.79 & 0.55 & 0.67 & $H$ \\
\hline Length of pregnancy (weeks) & 39.2 & 1.3 & 39.4 & 1.0 & $\mathrm{H}$ \\
\hline Weight of newborn $(g)$ & $3300 \cdot 9$ & 501.8 & $3295 \cdot 1$ & 378.5 & $\mathrm{H}$ \\
\hline Length of newborn (mm) & 501 & 18 & 500 & 14 & $\mathrm{H}$ \\
\hline No. of cigarettes/d & $3 \cdot 1$ & $5 \cdot 2$ & 1.6 & 3.5 & $\mathrm{NH}$ \\
\hline Apgar score at $1 \mathrm{~min}$ & 8.4 & 0.9 & 8.5 & 0.8 & $\mathrm{H}$ \\
\hline Apgar score at $5 \mathrm{~min}$ & 9.9 & 0.3 & $10 \cdot 0$ & 0.2 & $\mathrm{H}$ \\
\hline
\end{tabular}

$\mathrm{RI}$, recommended intake $(80 \mathrm{mg} / \mathrm{d}) ; \mathrm{H}$, homogeneous distribution of results (Student's $t$ test applied); $\mathrm{NH}$, non-homogeneous distribution of results (Mann-Whitney test applied).

* There were no significant differences between the established groups. 
Table 2. Ascorbic acid intake during the third trimester of pregnancy in fifty-seven women (Mean values and standard deviations)

\begin{tabular}{|c|c|c|c|c|}
\hline & \multicolumn{2}{|c|}{ Ascorbic acid intake $<\mathrm{R} \mid(n 12)$} & \multicolumn{2}{|c|}{ Ascorbic acid intake $\geq \mathrm{RI}(n$ 45) } \\
\hline & Mean & SD & Mean & SD \\
\hline $\begin{array}{l}\text { Ascorbic acid supplied by supplements }(\mathrm{mg} / \mathrm{d} \text { ) } \\
\text { Ascorbic acid supplied by supplements }+ \text { diet }\end{array}$ & 0 & & 10.7 & 48.5 \\
\hline Total intake $(\mathrm{mg} / \mathrm{d})$ & $55 \cdot 3^{*}$ & 13.9 & 174.8 & 70.9 \\
\hline $\begin{array}{l}\text { Coverage of } \mathrm{R} \mid(\%) \\
\text { Intake }<70 \% \text { of } \mathrm{R} \mid(\%)\end{array}$ & $69 \cdot 1^{*}$ & $17 \cdot 3$ & $218 \cdot 5$ & 88.6 \\
\hline $\begin{array}{l}\text { Ascorbic acid density }(\mathrm{mg} / 1000 \mathrm{~kJ}) \\
\text { INQ of ascorbic acid } \\
\text { INQ }<1(\%)\end{array}$ & $\begin{array}{l}6 \cdot 8^{\star} \\
0.85^{\star}\end{array}$ & $\begin{array}{l}1.8 \\
0.22\end{array}$ & $\begin{array}{c}18 \cdot 2 \\
2 \cdot 33\end{array}$ & $\begin{array}{l}6 \cdot 8 \\
0.95\end{array}$ \\
\hline
\end{tabular}

Table 3. Levels of ascorbic acid in maternal serum during the third trimester of pregnancy and in transition (days 13-14 and mature breast milk (day 40 ) in fifty-seven women

(Median values, mean values and standard deviations)

\begin{tabular}{|c|c|c|c|c|c|c|c|}
\hline & \multicolumn{3}{|c|}{ Ascorbic acid intake < RI (n 12) } & \multicolumn{3}{|c|}{ Ascorbic acid intake $\geq R I(n 45)$} & \\
\hline & Median & Mean & SD & Median & Mean & SD & \\
\hline \multicolumn{8}{|l|}{ Serum data, third trimester of pregnancy } \\
\hline $\begin{array}{l}\text { Serum ascorbic acid }(\mu \mathrm{mol} / \mathrm{l}) \\
\text { Low serum levels }(\%)\end{array}$ & $11 \cdot 2$ & $30 \cdot 1^{\star}$ & $36 \cdot 3$ & $98 \cdot 1$ & $101 \cdot 1$ & $168 \cdot 1$ & $\mathrm{NH}$ \\
\hline$<11.4 \mu \mathrm{mol} / \mathrm{I}$ & & 50.0 & & & 35.6 & & \\
\hline$<17.0 \mu \mathrm{mol} / 1$ & & $58 \cdot 3$ & & & 37.8 & & \\
\hline$<22.7 \mu \mathrm{mol} / \mathrm{l}$ & & 58.3 & & & 37.8 & & \\
\hline \multicolumn{8}{|l|}{ Ascorbic acid in milk } \\
\hline $\begin{array}{l}\text { Transition }(\mu \mathrm{mol} / \mathrm{l}) \\
\quad \text { Low breast milk levels }(<250 \mu \mathrm{mol} / \mathrm{l})(\%)\end{array}$ & $227 \cdot 2$ & $\begin{array}{r}255 \cdot 5^{\star} \\
50 \cdot 0\end{array}$ & $220 \cdot 3$ & 407.9 & $\begin{array}{r}437.8 \\
26.7\end{array}$ & 288.4 & $\mathrm{H}$ \\
\hline $\begin{array}{l}\text { Mature }(\mu \mathrm{mol} / \mathrm{l}) \\
\quad \text { Low breast milk levels }(<250 \mu \mathrm{mol} / \mathrm{l})(\%)\end{array}$ & 452.5 & $\begin{array}{r}471 \cdot 3 \\
33 \cdot 3\end{array}$ & $385 \cdot 0$ & $438-6$ & $\begin{array}{r}433.2 \\
28.9\end{array}$ & 337.8 & $\mathrm{H}$ \\
\hline
\end{tabular}

$\mathrm{R}$, recommended intake $(80 \mathrm{mg} / \mathrm{d}) ; \mathrm{H}$, homogeneous distribution of results (Student's $t$ test applied); $\mathrm{NH}_{1}$ non-homogeneous distribution of results (Mann-Whitney test applied).

Mean values were significantly different from those for the high intake group, ${ }^{\star} P<0.05$.

Borrud et al. (1993) reported that insufficient intake of ascorbic acid is uncommon, although many women take less than the recommended quantities of fruits and vegetables. In the present study, despite the fact that average values for ascorbic acid intake were $88 \%$ higher than those recommended, $21.1 \%$ of subjects showed ascorbic acid intakes lower than those recommended, and $9.3 \%$ showed intakes of below $70 \%$ recommended.

The concentrations of ascorbic acid in serum (Table 2) were similar to those obtained by other authors for the third trimester of pregnancy (García et al. 1974 (55.1 (SD 21.6) $\mu \mathrm{mol} / 1$ ); Knight et al. 1994 (51.1 (SD 22.7) $\mu \mathrm{mol} / 1$ ). The present values are, however, somewhat higher than those found by Bates et al. $(1982 ; 27.3 \mu \mathrm{mol} / \mathrm{l})$, Bates et al. (1983; 14.2-40.9 $\mu \mathrm{mol} / 1$ ), Dostálová (1984; 34.6 (SD 15.3) $\mu \mathrm{mol} / 1)$, and West et al. $(1994 ; 37.5-61.9 \mu \mathrm{mol} / \mathrm{l})$.

The percentages of deficient serum values were also similar to those found by Bates et al. $(1983 ; 79.8 \%$ of subjects with ascorbic acid intakes of $34.3 \mathrm{mg} / \mathrm{d}$ and $5.9 \%$ of those with intakes of $103.5 \mathrm{mg} / \mathrm{d}$ ), Dostálová (1984; $46.2 \%$ with moderate risk and $15.4 \%$ with high risk of deficiency), and Tlaskal \& Novakova (1990; low ascorbic acid levels in $23.3 \%$ of women who gave birth to mature, normal neonates, and $67 \%$ in those who gave birth to premature infants).

Subjects in group $\mathrm{H}$ showed significantly higher serum ascorbic acid levels than did those in group L (Table 2). The influence of ascorbic acid intake on serum levels of the vitamin has been reported by other authors. Bates et al. (1983) found that plasma ascorbate increased from 14.2 to $40.9 \mu \mathrm{mol} / 1$ as intake increased from 34.3 to $103.5 \mathrm{mg} / \mathrm{d}$. West et al. (1994) found higher serum levels of ascorbic acid in women who took vitamin-mineral supplements during the third trimester of pregnancy $(61.9 \mu \mathrm{mol} / 1$ compared with $37.5 \mu \mathrm{mol} / 1$ in those who took no supplements). Bates et al. (1983) also showed that a fasting plasma ascorbate level of at least $17 \mu \mathrm{mol} / 1$ in $97.5 \%$ of the population of lactating women in Keneba (a West African rural community) would require a daily ascorbic acid intake of about $117 \mathrm{mg}$. Levels of $28.4 \mu \mathrm{mol} / 1$ would require intakes of $150 \mathrm{mg} / \mathrm{d}$ and levels of $39.7 \mu \mathrm{mol} / 1$ would require $172 \mathrm{mg} / \mathrm{d}$.

The mean concentration of ascorbic acid in maternal milk (Table 3) was similar to that reported in other studies 
Table 4. Milk ascorbic acid levels found in other studies

\begin{tabular}{|c|c|c|c|}
\hline $\begin{array}{l}\text { Point during the } \\
\text { lactation period when } \\
\text { analysis was } \\
\text { performed }\end{array}$ & $\begin{array}{l}\text { Milk ascorbic acid levels } \\
\qquad(\mu \mathrm{mol} / \mathrm{l})\end{array}$ & $\begin{array}{c}\text { Breast milk } \\
\text { ascorbate: serum } \\
\text { ascorbate }\end{array}$ & Reference \\
\hline $\begin{array}{l}\text { Mature milk } \\
\text { Intakes forty times that recommended }\end{array}$ & $596 \cdot 2$ & & Anderson \& Pittard (1985) \\
\hline \multicolumn{4}{|l|}{ Mature milk } \\
\hline \multicolumn{4}{|l|}{ Maternal intake $(\mathrm{mg} / \mathrm{d})$ : } \\
\hline $34 \cdot 3$ & $193 \cdot 1$ & $13 \cdot 6$ & \multirow[t]{4}{*}{ Bates et al. (1983) } \\
\hline $58 \cdot 4$ & $269 \cdot 1$ & 11.85 & \\
\hline 81.1 & 301.5 & 11.06 & \\
\hline 103.5 & 312.9 & 7.65 & \\
\hline \multicolumn{4}{|l|}{ Mature milk } \\
\hline \multicolumn{4}{|l|}{ Maternal intake $(\mathrm{mg} / \mathrm{d})$ : } \\
\hline $\begin{array}{l}\text { virtually nil } \\
100\end{array}$ & $\begin{array}{l}113 \cdot 6 \\
340 \cdot 7\end{array}$ & $\begin{array}{r}10 \\
5\end{array}$ & Bates et al. (1994) \\
\hline $7-13$ weeks & $249 \cdot 8-897 \cdot 1$ & & Byerley \& Kirksey (1985) \\
\hline \multicolumn{4}{|l|}{ Maternal intake $(\mathrm{mg} / \mathrm{d})$ : } \\
\hline$<100$ & $473 \cdot 0$ & & \\
\hline 100-199 & 613.2 & & \\
\hline $200-399$ & 550.2 & & \\
\hline $400-999$ & 607.5 & & \\
\hline$\geq 1000$ & 653.0 & & \\
\hline Mature milk $(>21 d)$ & $227 \cdot 1$ (SD 56.8) & & Committee on Nutrition (1985) \\
\hline Mature milk & $244.2-494 \cdot 0$ & & Fomon (1974) \\
\hline $0-6$ months & $295 \cdot 3$ & & Schwartz (1985) \\
\hline \multicolumn{4}{|l|}{$5-7 d$} \\
\hline \multicolumn{4}{|l|}{ Maternal intake $(\mathrm{mg} / \mathrm{d})$ : } \\
\hline $\begin{array}{r}83 \\
152\end{array}$ & $301.5($ SD 97.1) & 6.90 & \multirow[t]{2}{*}{ Sneed et al. (1981) } \\
\hline 152 & 346.4 (SD 56.8$)$ & 7.01 & \\
\hline \multicolumn{4}{|l|}{$43-45 d$} \\
\hline \multicolumn{4}{|l|}{ Maternal intake $(\mathrm{mg} / \mathrm{d})$ : } \\
\hline 202 & 369.1 (SD 113.6) & 6.44 & \\
\hline 193 & $408.8(S D 113.6)$ & $6 \cdot 16$ & \\
\hline Mature milk & $244.2-494.0$ & & Thomas et al. (1979) \\
\hline
\end{tabular}

(Fomon, 1974; Thomas et al. 1979; Sneed et al. 1981; Byerley \& Kirksey, 1985; Schwartz, 1985). However, it was greater than that recorded in still others (Bates et al. 1983, 1994; Committee on Nutrition, 1985) (Table 4).

In agreement with Sneed et al. (1981) and Udipi et al. (1985), a tendency was seen for milk ascorbic acid levels to rise as lactation progressed. Ascorbic acid levels in mature milk were slightly higher than those of transition milk, although the difference was not significant (Table 3). Subjects in group $\mathrm{H}$ showed significantly higher transition milk ascorbic acid levels than did those in group L (Table 3).

The influence of ascorbic acid intake on maternal milk concentrations has been recognized by many authors (Bates et al. 1983, 1994; Anderson \& Pittard, 1985; Institute of Medicine, 1991) (Table 4). Bates et al. (1983) studied the relationship between breast milk ascorbic acid levels and intake in European women, and concluded that intakes of $80-100 \mathrm{mg} / \mathrm{d}$ are needed to achieve levels of 284 $340.7 \mu \mathrm{mol} / 1$.

It would appear that the changes produced in breast milk ascorbic acid levels are less pronounced than those seen in serum (Bates et al. 1982, 1983; Byerley \& Kirksey, 1985). The breast milk ascorbate : serum ascorbate ratio decreased with increased intake and serum vitamin C levels (Table 4). This shows that mammary tissue becomes saturated with the vitamin when intake is high (Anderson \& Pittard, 1985; Byerley \& Kirksey, 1985). Byerley \& Kirksey (1985) indicated the probable existence of a regulatory mechanism in mammary cells to prevent elevation of milk vitamin $\mathrm{C}$ concentrations beyond a certain saturation level.

Some authors dispute the influence of intake on breast milk levels. Salmenpera (1984) has suggested that the ascorbic acid status of breast-fed infants of mothers with inadequate status may remain optimal. Others have reported that when intake is low, breast milk ascorbic acid levels are sensitive to supplementation. However, when intake is high, breast milk levels are much less sensitive (Thomas et al. 1979; Sneed et al. 1981).

The results of the present study show that there is a relationship between ascorbic acid intake and serum and milk levels. Although the mean intake of ascorbic acid was $188 \%$ of that recommended, $21.1 \%$ of subjects showed lower than recommended intakes, $38.6 \%$ showed serum levels below $11.4 \mu \mathrm{mol} / \mathrm{l}, 33.3 \%$ showed $<250 \mu \mathrm{mol} / 1$ in transition milk and $31.5 \%$ showed $<250 \mu \mathrm{mol} / 1$ in mature milk.

In agreement with Borrud et al. (1993), we consider that efforts to improve the nutritional status of pregnant and lactating women would be well served if all women of child-bearing age were encouraged to maximize the nutritional quality of their diets. It is especially important to recommend an increase in the consumption of fruit and vegetables during pregnancy, not only to raise ascorbic acid intake, but also that of carbohydrates, fibre, and other 
vitamins, especially folates. Folate deficiency has been associated with many maternal and fetal complications including low birth weight, detachment of the placenta and neural-tube defects (O'Connor, 1994; Keizer et al. 1995).

\section{Acknowledgements}

This work was supported by grants from the Fondo de Investigaciones Sanitarias de la Seguridad Social (FISss), Spain (reference no. 92/1181).

\section{References}

Açkurt F, Wetherlit H, Löker M \& Hacibekiroglu M (1995) Biochemical assessment and nutritional status in pre- and postnatal Turkish women and outcome of pregnancy. European Journal of Clinical Nutrition 49, 613-622.

Anderson DM \& Pittard WB (1985) Vitamin E and C concentrations in human milk with maternal megadosing: a case report. Joumal of the American Dietetic Association 85, $715-717$

Antal M, Regöly-Mérei A, Varsányi H, Biró L, Sági K, Molnár DV, Zajkás G, Nagy K, Avar Z \& Biró G (1997) Nutritional survey of pregnant women in Hungary. International Journal for Vitamin and Nutrition Research 67, 115-122.

Ash S (1995) Dietary intakes of pregnant women in Sydney, New South Wales. Australian Journal of Nutrition and Dietetics 52, 149-153.

Bates CJ, Prentice AM \& Paul AA (1994) Seasonal variations in vitamins $\mathrm{A}, \mathrm{C}$, riboflavin and folate intakes and status of pregnant and lactating women in a rural Gambian community: some possible implications. European Journal of Clinical Nutrition 48, 660-668.

Bates CJ, Prentice AM, Prentice A, Lamb WH \& Whitehead RG (1983) The effect of vitamin C supplementation on lactating women in Keneba, a West African rural community. International Journal for Vitamin and Nutrition Research 53, 68-76.

Bates CJ, Prentice AM, Prentice A, Paul AA \& Whitehead RG (1982) Seasonal variations in ascorbic acid status and breast milk ascorbic acid levels in rural Gambian women in relation to dietary intake. Transactions of the Royal Society of Tropical Medicine and Hygiene 76, 341-347.

Beutler HO \& Beinstingl G (1980) Bestimmung von LAscorbinsäure in Lebensmitteln (Determination of L-ascorbic acid in foods). Deutsche Lebensmitteln-Rundschau 76, 69-75.

Borrud LG, Krebs-Smith SM, Friedman L \& Guenther PM (1993) Food and nutrient intakes of pregnant and lactating women in the United States. Journal of Nutrition Education 25, 176-185.

Byerley LO \& Kirksey A (1985) Effects of different levels of vitamin $\mathrm{C}$ intake on the vitamin $\mathrm{C}$ concentration in human milk and the vitamin $\mathrm{C}$ intakes of breast-fed infants. American Journal of Clinical Nutrition 41, 665-671.

Casanueva E, Polo E, Tejero E \& Meza C (1993) Premature rupture of amniotic membranes; a functional assessment of vitamin C status during pregnancy. Annals of the New York Academy of Sciences 678, 369-370.

Committee on Nutrition (1985) Composition of human milk: normative data. In Pediatric Nutrition Handbook, 2nd ed., pp. 363-368. Illinois: American Academy of Pediatrics.

Departamento de Nutrición (1994) Ingestas Recomendadas de Energía y Nutrientes para la Población Española (Recommended Energy and Nutrient Intakes for the Spanish Population). Madrid: Departamento de Nutrición.

Dostálová L (1984) Vitamin status during puerperium and lactation. Annals of Nutrition and Metabolism 28, 385-408.
Fomon SJ (1974) Infant Nutrition, 2nd ed., p. 362. Philadelphia, PA: W.B. Saunders.

García PA, Brewer WB, Merritt CW \& Mead HB (1974) Nutritional status of adolescent primigravidae; blood indices during pregnancy and postpartum. Iowa State Journal Research Medicae 49, 219-229.

González-Cossio T \& Delgado H (1991) Functional consequences of maternal malnutrition. World Review of Nutrition and Dietetics 64, 139-173.

Henninger $\mathbf{G}$ (1981) Enzymatische Bestimmung von L-Ascorbinsaure in Lebensmitteln, Pharmzeutika und biologischen flussingkeiten (Enzymatic determination of L-ascorbic acid in foods, medicines and biological liquids). Alimenta 20, 1214.

Hunt I, Murphy N, Martner-Hewes P, Faraji B, Swendseid M, Reynolds R, Sanchez A \& Mejia A (1987) Zinc, vitamin B-6 and other nutrients in pregnant women attending prenatal clinics in Mexico. American Journal of Clinical Nutrition 46, 563-569.

Institute of Medicine (1991) Nutrition During Lactation, pp. 57219. Washington, DC: National Academy Press.

Instituto de Nutrición (1994) Tablas de Composición de Alimentos Españoles (Tables of Composition of Spanish Foods). Madrid: Instituto de Nutrición.

Jendryczko A \& Tomala J (1995) The total free radical trapping ability of blood plasma in eclampsia. Zentralblatt fuer Gynakologie 117, 126-129.

Job J, Capra S \& Ash S (1995) Nutritional assessment of pregnant teenagers attending a metropolitan, public, maternity hospital in Brisbane. 1. Nutrient intakes. Australian Journal of Nutrition and Dietetics 52, 76-82.

Johnson RK, Goran MI \& Pohlman ET (1994) Correlates of overand underreporting of energy intake in healthy older men and women. American Journal of Clinical Nutrition 59, 1286-1290.

Keizer SE, Gibson RS \& O'Connor DL (1995) Postpartum folic acid supplementation of adolescents: impact on maternal folate and zinc status and milk composition. American Journal of Clinical Nutrition 62, 377-384.

Keller HE \& Salkeld RM (1988) Bereichswerte van analysenparametern für den Vitaminstatus (Analytical parameters applicable to the determination of vitamin status), GCR B 106, 334 .

King JC \&Weininger J (1991) Embarazo y lactancia (Pregnancy and lactation). In Conocimientos Actuales Sobre Nutricion (Present Knowledge on Nutrition), pp. 362-369. Washington, DC: ILSI-North America.

Knight EM, Spurlock BG, Edwards CH, Johnson AA, Oyemade UJ, Cole OJ, West WL, Manning M, James H, Laryea H, Westney OE, Jones S \& Westney LS (1994) Biochemical profile of African American women during three trimesters of pregnancy and at delivery. Journal of Nutrition 124, 943S953S.

Kübler W (1988) Vitaminmagel und Folgen (Suboptimal vitamin supply and its sequelae). Bibliotheca Nutritio et Dieta 42, 88-100.

O'Connor DL (1994) Folate status during pregnancy and lactation. In Nutrient Regulation During Pregnancy, Lactation and Infant Growth, pp. 151-166 [L Allen, J King and B Lonnerdal, editors]. New York: Plenum Press.

Ortega RM, Andrés P, Martínez RM \& López-Sobaler AM (1997a) Vitamin A status during the third trimester of pregnancy in Spanish women: influence on concentrations of vitamin A in breast milk. American Joumal of Clinical Nutrition 66, 564-568.

Ortega RM, Andrés P, Martínez RM, López-Sobaler AM \& Quintas ME (1997b) Zinc levels in maternal milk: the influence of nutritional status with respect to zinc during the third trimester of pregnancy. European Journal of Clinical Nutrition 51, 253-258. 
Ortega RM, Gaspar MJ \& Cantero M (1996a) Influence of maternal serum lipids and maternal diet during the third trimester of pregnancy on umbilical cord blood lipids in two populations of Spanish newborns. International Journal for Vitamin and Nutrition Research 66, 250-257.

Ortega RM, Gaspar MJ \& Moreiras O (1994) Dietary assessment of a pregnant Spanish women group. International Journal for Vitamin and Nutrition Research 64, 130-134.

Ortega RM, Requejo AM, Quintas ME, Sánches-Quiles B, LópezSobaler AM \& Andrés P (1996b) Estimated energy balance in female university students: differences with respect to body mass index and concern about body weight. International Journal of Obesity 20, 1127-1129.

Patton S, Canfield LM, Huston GE, Ferris AM \& Jensen RG (1990) Carotenoids of human colostrum. Lipids 25, 159-165.

Pfeffer F, Valdés-Ramos R, Avila-Rosas H, Meza C \& Casanueva E (1996) Iron, zinc and vitamin C nutritional status is not related to weight gain in pregnant women. Nutrition Research 16, 555-564.

Picone T, Allan LH, Schramm MH \& Olsen D (1982) Pregnancy outcome in North American women. 1. Effects of diet, cigarette smoking and psychological stress on maternal weight gain. American Journal of Clinical Nutrition 36, 1205-1213.

Salmenpera L (1984) Vitamin C nutrition during prolonged lactation: optimal in infants while marginal in some mothers. American Journal of Clinical Nutrition 40, 1050-1056.

Schwarz KB (1985) Vitamins in Nutrition in Pediatrics, pp. 5866. Boston, MA: Little Brown.

Sneed SM, Zane C \& Thomas MR (1981) The effects of ascorbic acid, vitamin $B_{6}$, vitamin $B_{12}$, and folic acid supplementation on the breast milk and maternal nutritional status of low socioeconomic lactating women. American Journal of Clinical Nutrition 34, 1338-1346.

Thomas MR, Kawamoto J, Sneed SM \& Eakin R (1979) The effects of vitamin $C$, vitamin $B_{6}$, and vitamin $B_{12}$ supplementation on the breast milk and maternal status of well-nourished women. American Journal of Clinical Nutrition 32, 1679 1685.

Tlaskal P \& Novakova V (1990) Vitamins C and E in neonates and their mothers. Ceskoslovenska Pediatrika 45, 339-343.

Udipi SA, Kirksey A, West K \& Giacoia G (1985) Vitamin B , vitamin $C$ and folacin levels in milk from mothers of term and preterm infants during the neonatal period. American Journal of Clinical Nutrition 42, 522-530.

West WL, Knight EM, Edwards CH, Manning M, Spurlock B, James H, Johnson AA, Oyemade UJ, Cole OJ, Westney OE, Laryea H, Jones S \& Westney LS (1994) Maternal low level lead and pregnancy outcomes. Journal of Nutrition 124, $981 \mathrm{~S}$ $986 \mathrm{~S}$.

Wonnacott HW \& Wonnacott RJ (1977) Introductory Statistics. New York: John Wiley and Sons, Inc.

World Health Organization (1976) Methodology of Nutritional Surveillance. Technical Report Series no. 53, pp. 20-60. Geneva: World Health Organization.

World Health Organization (1985) Energy and Protein Requirements. Technical Report Series no. 724, pp. 71-80. Geneva: World Health Organization.

Zeman FJ \& Ney DM (1988) Nutrition during pregnancy and lactation. In Applications of Clinical Nutrition, pp. 54-72. New Jersey: Prentice Hall. 